\title{
Options for meeting the ecological Reserve for a raised Clanwilliam Dam
}

\author{
CA Brown ${ }^{1 *}$, E van der Berg ${ }^{2}$, A Sparks ${ }^{2}$ and RN Magoba ${ }^{1}$ \\ ${ }^{1}$ Southern Waters Ecological Research and Consulting cc, Freshwater Research Unit, University of Cape Town, \\ Private Bag Rondebosch, 7700 , South Africa \\ ${ }^{2}$ Aurecon (Pty) Ltd, PO Box 1347, Cape Town, 8000, South Africa
}

\begin{abstract}
A recent evaluation of the potential raising of Clanwilliam Dam included an assessment of whether the operation of the dam would meet the flow quality and quantity requirements for the protection of the downstream river and its estuary, taking Olifants/Doring River basin-level considerations into account.

The implications of meeting the ecological Reserve of the Olifants River downstream of Clanwilliam Dam to Bulshoek Weir, downstream of Bulshoek Weir to the confluence with the Doring River, and at the estuary, were assessed in terms of the impact on system yield. Some adjustments were made to the ecological Reserve to maximise the yield from a raised Clanwilliam Dam, in return for protection of the vitally important Doring River. Irrigation releases from Clanwilliam Dam were also restructured so that they met the ecological Reserve requirement for small floods of short duration to promote spawning in Clanwilliam yellowfish (Labeobarbus capensis). The assessments presented demonstrate that small adjustments in the requirements that form the ecological Reserve can greatly enhance the possibility, and reduce the costs, of successful implementation.
\end{abstract}

Keywords: Clanwilliam Dam raising, Clanwilliam yellowfish, ecological Reserve, ecological condition, environmental flows, water management tradeoffs

\section{Introduction}

The South African National Water Act (NWA, 1998) provides for the protection of water resources through the apportioning of an agreed amount of the water available in a system to maintain the natural environment in some pre-agreed condition. To fulfill its purpose, this water needs to be of an appropriate volume and quality, and be available at the appropriate time of the year, and is known as the ecological Reserve. To arrive at the ecological Reserve, the environmental flows (EFs) for the maintenance of affected rivers, estuaries, wetlands and groundwater are first determined for a range of future conditions. These are then assessed against other requirements in the basin, such as provision of water for off-stream use, as part of a consultative process to decide on acceptable future conditions for the various ecosystems (Dollar et al., 2010). The agreed future condition and the EFs for maintaining such become the ecological Reserve.

The Department of Water Affairs (DWA) is responsible for implementing the ecological Reserve for all significant water resources in South Africa, gradually over time. Importantly, however, new bulk infrastructure or any changes to existing bulk infrastructure, requires implementation of the ecological Reserve as part and parcel of the process. This is the case in the Olifants-Doring Basin, where concerns about the integrity of the Clanwilliam Dam necessitate remedial work on the wall, and opened the possibility of increasing its yield at the same time by raising the dam wall, which would trigger the need for releases to meet the ecological Reserve for the downstream river and its estuary.

\footnotetext{
* To whom all correspondence should be addressed.

용 +2721-4653135; fax: $+2721-4653901$;

e-mail:cate@southernwaters.co.za

Received 22 December 2009; accepted in revised form 14 July 2010.
}

This paper is a synthesis of a number of studies, relevant to the issue of Reserve releases from Clanwilliam Dam, including the assessment of the EFs for the Olifants River (Brown et al., 2006a; b) and estuary (Taljaard et al., 2006), a basin-level scenario assessment (Brown et al., 2006c), and a feasibility study for the raising of Clanwilliam Dam (De Wet, 2007).

The main ecological, social and economic considerations relevant to the basin are introduced, and a description of the water resource situation and extant infrastructure is provided for background. The circumstances leading to, and consequences of, various tradeoffs for the ecosystem, with regard to the implementation of the ecological Reserve are discussed in the context of off-stream water demands and potential future bulk water developments in the Olifants-Doring Basin, and specifically the potential raising of Clanwilliam Dam on the Olifants River upstream of its confluence with its main tributary, the Doring River.

\section{The study area}

The Olifants-Doring Basin is located on the west coast of South Africa. The Olifants River rises in the Agter Witzenberg Mountains to the north of Ceres. Most of the surface flows originate in the Cederberg Mountains, located along the eastern flank of its middle reaches. The main stem of the river is approximately $250 \mathrm{~km}$ long, initially flowing through a steep gorge, but eventually widening and flattening into a wide floodplain and a major estuary at the coast. Its major tributary, the Doring River, also rises in the Agter Witzenberg Mountains, but flows down the opposite side of the Cederberg Mountains.

The total natural mean annual runoff (MAR) of the Olifants River is approximately $1055 \times 10^{6} \mathrm{~m}^{3} / \mathrm{a}$, but this has been significantly reduced by abstractions, mainly for irrigation (Sparks and Cullis, 2007), and current inflows to the estuary are approximately $718.4 \times 10^{6} \mathrm{~m}^{3} / \mathrm{a}$. Water resources are not 
evenly distributed over the basin. Precipitation varies from up to $1500 \mathrm{~mm} / \mathrm{a}$ in the Cederberg Mountains in the southwest, to less than $100 \mathrm{~mm} / \mathrm{a}$ in the northern coastal areas, and the mean annual potential evaporation is more than an order of magnitude higher than the rainfall over most of the area. The summer months, November to February, are warm and dry, and climate variation is extreme. The Olifants River is naturally perennial but flows in the Doring River are naturally seasonal, with the flow in the river ceasing for several days to several months each year.

Accurate daily flow data are not available for the Olifants River, or for any of its tributaries, upstream of Clanwilliam Dam, due to a paucity of functioning gauging weirs. Flow modelling indicated that present-day flows throughout the basin are generally lower than naturalised flows, with summer low flows considerably reduced relative to the natural levels, such that in the Olifants River upstream of Clanwilliam Dam surface flow now ceases in the summer months.

The quality of water in the upper and middle Olifants River is good but downstream of the confluence with the Doring River nitrification and salinities become a problem, particularly during March and April.

The study area falls within the Greater Cederberg Biodiversity Corridor, a biodiversity conservation project aimed at conserving critical habitat types in the region (Low et al., 2004). The Olifants and Doring River system has also been highlighted as a 'hotspot' of freshwater fish diversity in South Africa (Skelton et al., 1995) because it contains 8 endemic fish species that occur in no other river systems, as well as several other indigenous fish species. All of these are endangered, mainly as a result of agricultural activities, flow alterations and the impact of introduced species, such as bass and carp. In addition, the Doring River, and some of the tributaries, are virtually unspoiled by human impacts and have a very high ecological importance and sensitivity.

The Olifants River Estuary, located approximately $250 \mathrm{~km}$ north-west of Cape Town, is 1 of only 3 permanently open estuaries on the west coast of South Africa, together with the Berg and Orange River estuaries. Based on its size, zonal-type rarity, habitat diversity and biodiversity, it is considered to be the second most important system in South Africa (Turpie et al., 2002). The estuary also plays an important role in bird migration and the conservation of waterbirds (Taljaard et al., 2006).

Agriculture is the chief economic activity in the basin and it contributes approximately $45 \%$ of the economic output of the basin (Shippey and Van der Berg, 2004). Citrus farming in the area is important nationally (Kempthorne et al., 2007), as is wine making. Other economic sectors are mainly those serving the agricultural sector, although tourism is also important. The population is mostly rural and dispersed over a large area, with some concentration in small towns such as Citrusdal, Clanwilliam and Vredendal.

The area has high poverty levels and extreme dependence on agriculture and subsistence activities. Resource-poor farmers have limited access to good quality agricultural land and have been historically sidelined in terms of access to water (Kempthorne et al., 2007). The communities at Ebenhaeser (in the estuary) and Papendorp are particularly vulnerable to poverty, with approximately 3500 people almost solely dependent on the river for their subsistence activities of fishing and irrigated agriculture. The estuary is also a nursery for various line-fish that underpin the West Coast fisheries. Thus, the cost of degrading the estuary would be high in terms of negative effects on livelihoods (Kempthorne et al., 2007).

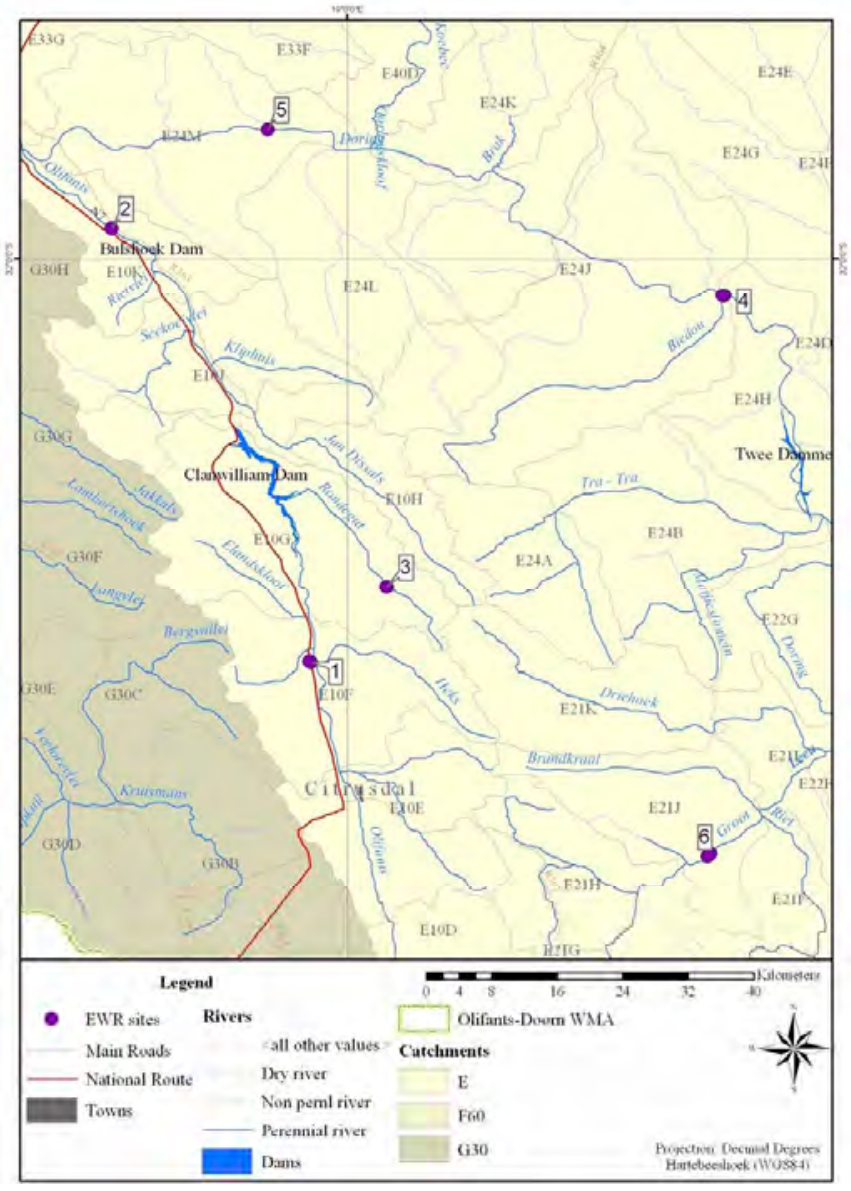

Figure 1

Map of the EF sites in the Olifants-Doring basin

Various small towns, and some other users, receive water from the river, but the bulk of the water is used for irrigation. Irrigation-related infrastructure in the basin consists of runof-river abstraction and diversions of the river into irrigation canals. There are also numerous farm dams in the upper parts of the basin. In the middle and lower reaches, the Olifants River Government Water Scheme comprises Clanwilliam Dam, Bulshoek Weir and a $186 \mathrm{~km}$ long irrigation canal system.

Clanwilliam Dam is a 43-m high mass gravity concrete structure with a centrally situated overspill section, with 13 crest gates. The maximum discharge capacity of the 2 bottom outlet pipes is approximately $10 \mathrm{~m}^{3} / \mathrm{s}$ (Bester et al., 2006). The Bulshoek Weir is a gated stone-masonry gravity structure. Water is diverted into one canal system at Clanwilliam Dam (live storage $122 \times 10^{6} \mathrm{~m}^{3}$ ) and is also released into the river to flow to Bulshoek Weir (live storage $5.7 \times 10^{6} \mathrm{~m}^{3}$ ), approximately $30 \mathrm{~km}$ downstream, where it is diverted into another canal system. The Jan Dissels River also joins the Olifants River between Clanwilliam Dam and Bulshoek Weir. The total irrigated area dependent on Clanwilliam Dam and Bulshoek Weir is more than $140 \mathrm{~km}^{2}$ at an estimated 1:5 year assurance of supply. During drought years when Clanwilliam Dam does not fill, restrictions are placed on the irrigation water users. There is a need for an improved assurance of supply for irrigated agriculture and for growth, and a need to allocate additional water to resource-poor farmers in the area.

No ecological Reserve releases are currently made from either Clanwilliam Dam or Bulshoek Weir. In dry periods, leakage from the Bulshoek Weir into the downstream river is also pumped back into the canals. 


\begin{tabular}{|l|l|l|c|c|c|}
\hline \multicolumn{2}{|c|}{ Location and condition of the river EF site } \\
\hline $\begin{array}{l}\text { EF } \\
\text { site }\end{array}$ & River & Location & $\begin{array}{c}\text { Natural } \\
\text { MAR } \\
\left(\mathbf{M m}^{3} / \mathbf{a}\right)\end{array}$ & $\begin{array}{c}\text { Present } \\
\text { day MAR } \\
\mathbf{( M m} \text { /a) }\end{array}$ & $\begin{array}{c}\text { Ecological } \\
\text { condition }\end{array}$ \\
\hline 1 & Olifants & Adjacent to the N7 downstream of the confluence with the Hex River & 332 & 275 & D \\
\hline 2 & Olifants & Downstream of Bulshoek Weir, just downstream of Cascade Pools & 519 & Not known & E \\
\hline 3 & Rondegat & $\begin{array}{l}\text { Upstream of the Algeria staff accommodation, on the road between } \\
\text { Algeria and Clanwilliam }\end{array}$ & 7.7 & 7.3 & B \\
\hline 4 & Doring & Immediately upstream of the confluence with the Biedou River & 420 & 320 & B \\
\hline 5 & Doring & At Ou Drif & 511 & 401 & B \\
\hline 6 & Groot & Upstream of the Mount Cedar bridge & 138 & 104 & B/C \\
\hline
\end{tabular}

\begin{tabular}{|l|l|}
\hline \multicolumn{2}{|c|}{ Ecological condition categories (from Kleynhans, 1996) } \\
\hline Category & Description \\
\hline A & Unmodified, natural \\
\hline B & $\begin{array}{l}\text { Largely natural with few modifications. A small change in natural habitats and biota may have taken place but the } \\
\text { ecosystem functions are essentially unchanged. }\end{array}$ \\
\hline C & $\begin{array}{l}\text { Moderately modified. A loss and change of natural habitat and biota have occurred but the basic ecosystem functions } \\
\text { are still predominantly unchanged. }\end{array}$ \\
\hline D & Largely modified. A large loss of natural habitat, biota and basic ecosystem functions has occurred. \\
\hline E & The loss of natural habitat, biota and basic ecosystem functions is extensive. \\
\hline F & $\begin{array}{l}\text { Critically modified. An almost complete loss of natural habitat, biota and ecosystem functioning. In the worst cases, } \\
\text { the changes are irreversible. }\end{array}$ \\
\hline
\end{tabular}

\section{The EF studies}

The riverine and the estuarine EFs were determined using standard DWA methodologies, and included a socio-economic assessment of a series of basin-wide flow scenarios (Brown et al., 2006a; Taljaard, 2006). The following is summarised from Brown et al. (2006a):

\section{River EFs}

The EF determination for the river focused on 6 sites (Fig. 1). The location of sites for the river EF was intended to provide information for the rivers upstream of the confluence of the Olifants and Doring Rivers, as it was expected that, for the lower Olifants River, the EF for the estuary would be greater than that for the river. Although it would have been extremely useful, it was not possible to locate an EF site on the Olifants River between Clanwilliam Dam and Bulshoek Weir because the riparian and instream vegetation had been severely burnt just before the study, and would not have yielded the sorts of information needed for the EF determination. When information was needed for either the lower Olifants River or the reach between Clanwilliam Dam and Bulshoek Weir, it was extrapolated from the nearest, relevant EF site.

The DRIFT methodology was used for the riverine ecological assessments (King et al., 2003). This approach allows for the generation of scenarios of different river condition linked with their EFs (Brown and Joubert, 2003), which assisted in the evaluation of a series of basin-wide water-resource developments. Essentially, sites on the more heavily-populated and cultivated Olifants River were in a poorer condition than those on the Doring River or on the tributaries (Table 1). Site 1 on the Olifants River upstream of Clanwilliam Dam was in a D category (Table 2), mainly as a result of excessively low summer flows (cessation of flow at times), cultivation of the floodplains and riparian zones and high numbers of bass. Site 2, downstream of Bulshoek Weir was in an E category, resulting from loss of floods and low flows, reduced sediment supply, encroachment of reeds and palmiet (Prionium palmitum), and cultivation of flood terraces, which have completely and, to all intents and purposes, irreversibly, changed the character of the river. Sites 3 to 5 were in a B category, i.e., largely natural, and Site 6 was in a B/C, mainly because there were some water quality issues, but the habitat was in excellent condition. The EF requirements for maintaining the sites in their current condition were correspondingly lower for the sites in poorer condition (Table 3).

\begin{tabular}{|c|c|c|c|}
\hline The & $\begin{array}{c}\text { Table } 3 \\
\text { for the study sites, excluding } \\
\text { period floods }\end{array}$ & 2 & rn \\
\hline Site & Target condition & $\mathrm{Mm}^{3} / \mathrm{a}$ & $\%$ nMAR \\
\hline EF Site 1 & Maintain present condition (D) & 88 & $26 \%$ \\
\hline EF Site 2 & Maintain present condition (E) & 48.3 & $9 \%$ \\
\hline & Improve to a D category & \pm 194 & $38 \%$ \\
\hline EF Site 3 & Maintain present condition (B) & 3 & $38 \%$ \\
\hline EF Site 4 & Maintain present condition $(\mathrm{B} / \mathrm{C})$ & 145 & $34 \%$ \\
\hline EF Site 5 & Maintain present condition (B) & 175 & $33 \%$ \\
\hline EF Site 6 & Maintain present condition $(\mathrm{B} / \mathrm{C})$ & 47 & $34 \%$ \\
\hline
\end{tabular}

In terms of DWA policy, Site 2 should be restored to at least a $\mathrm{D}$ category, which would require an additional low-flow of $146 \times 10^{6} \mathrm{~m}^{3} / \mathrm{a}$. This would, however, severely impact on economic activity, as it would reduce amount of water available for off-stream use. There was unanimous agreement from the ecologists that the attainment of a D category at EF Site 2 was unrealistic, and a 'residual flow' was instead recommended, to maintain the riparian and instream vegetation in the reach and keep the reach in an E category. 


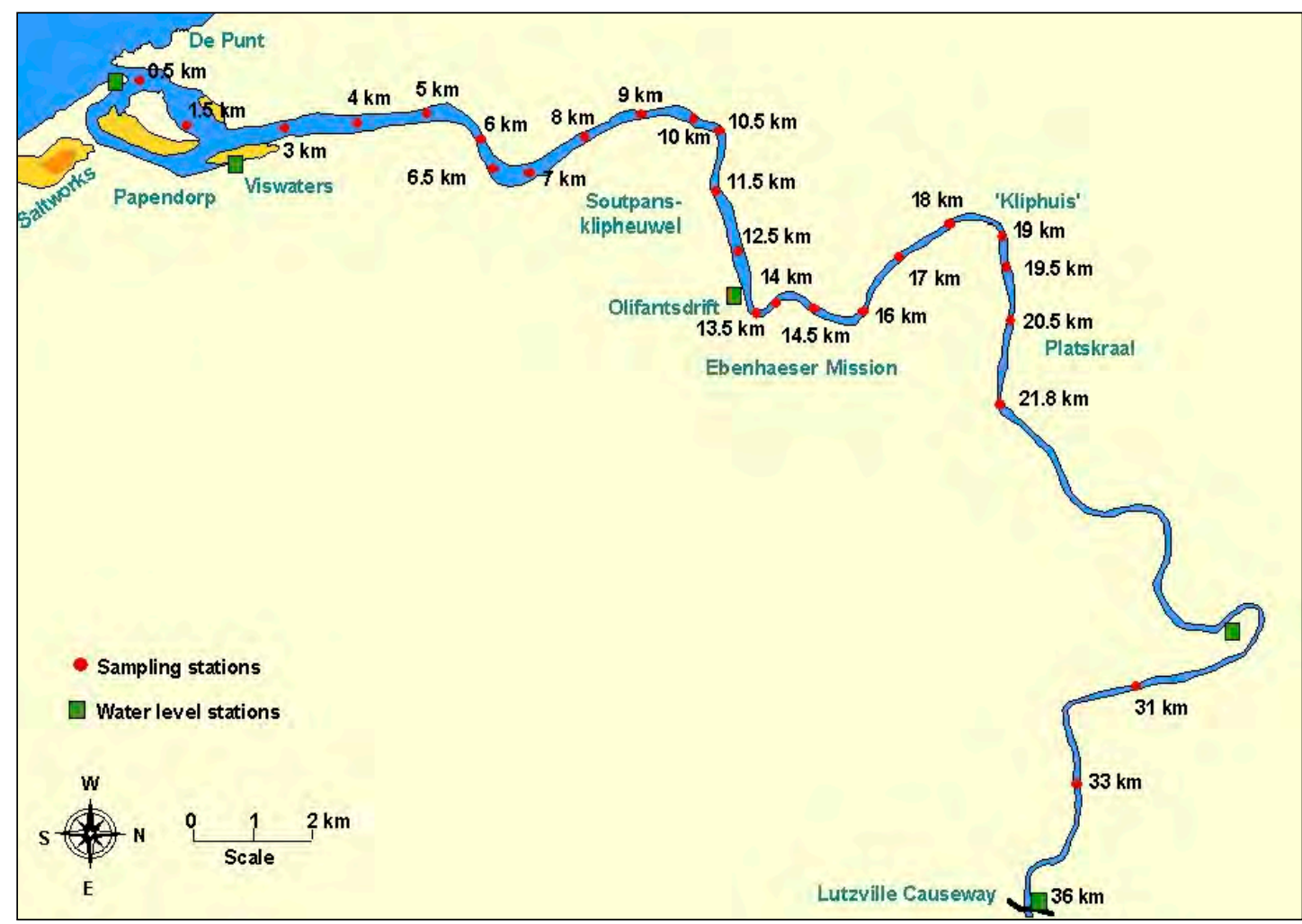

Figure 2

Map showing

extent of the

Olifants Estuary

\section{Estuarine EF}

The Olifants River Estuary is permanently open to the sea and the tidal influence extends some $36 \mathrm{~km}$ upstream (Fig. 2). The productivity of the estuary is, thus, particularly sensitive to decreases in river flows, flood frequencies and water quality. The estuary itself is still relatively undeveloped, but its condition is affected by a reduction in the volume and variability of freshwater inflows. The present daily flow to the estuary is about $66 \%$ of natural, but much of the reduction in flows is concentrated in the dry summer months, when flows are extremely low $\left(<1 \mathrm{~m}^{3} / \mathrm{s}\right)$ and of a poor quality as they are strongly influenced by return flow from irrigation along the river.

The present (2005) ecological condition of the estuary is a $\mathrm{C}$ category, but this is on a negative trajectory (Taljaard et al.,
2006). Also, given its local, regional and national importance, Department of Environmental Affairs policy dictates that the condition of the estuary should be improved to a B category. Thus, EFs were determined for maintaining the estuary in a $\mathrm{C}$ category, i.e., stabilising the negative trajectory (Table 4), and for improving the condition to a B category, which would require an additional $203.3 \times 10^{6} \mathrm{~m}^{3} / \mathrm{a}$ over and above present day flows into the estuary $\left(800.3 \times 10^{6} \mathrm{~m}^{3} / \mathrm{a}\right.$ in total; Taljaard et al., 2006).

\section{Basin-level EF assessment of water-resource development options}

The basin-level EF assessment considered a suite of scenarios, which approximated the effect that future bulk water resource developments would have on river flows and inflows to the

\begin{tabular}{|c|c|c|c|c|c|c|c|c|c|c|c|c|}
\hline \multicolumn{13}{|c|}{$\begin{array}{c}\text { Table } 4 \\
\text { Summary of the flow distribution of the EF for the Olifants Estuary to maintain an Ecological Category C } \\
\text { (Taljaard et al., 2006) }\end{array}$} \\
\hline & Oct & Nov & Dec & Jan & Feb & Mar & Apr & May & Jun & Jul & Aug & Sep \\
\hline 99\%ile & 42.17 & 28.76 & 21.52 & 37.04 & 24.33 & 7.43 & 95.80 & 153.56 & 471.91 & 470.40 & 210.01 & 149.81 \\
\hline $90 \%$ ile & 23.61 & 7.85 & 7.27 & 3.66 & 3.84 & 4.07 & 9.43 & 66.69 & 112.14 & 150.96 & 116.78 & 65.34 \\
\hline $80 \%$ ile & 11.33 & 3.96 & 2.33 & 1.62 & 1.80 & 2.11 & 4.34 & 17.92 & 72.07 & 78.37 & 81.56 & 40.07 \\
\hline $70 \%$ ile & 7.85 & 2.16 & 1.64 & 1.53 & 1.46 & 1.73 & 2.24 & 8.84 & 44.03 & 53.49 & 52.19 & 30.07 \\
\hline $60 \%$ ile & 5.44 & 1.67 & 1.52 & 1.53 & 1.45 & 1.39 & 1.79 & 4.84 & 21.61 & 38.99 & 33.68 & 20.61 \\
\hline $50 \%$ ile & 4.36 & 1.42 & 1.52 & 1.53 & 1.41 & 1.32 & 1.23 & 2.33 & 14.39 & 22.60 & 27.35 & 13.96 \\
\hline 40\%ile & 3.17 & 1.36 & 1.52 & 1.53 & 1.41 & 1.32 & 1.15 & 1.65 & 9.02 & 12.62 & 17.14 & 12.10 \\
\hline $30 \%$ ile & 2.00 & 1.36 & 1.52 & 1.53 & 1.41 & 1.32 & 1.15 & 0.90 & 5.01 & 8.22 & 11.91 & 8.78 \\
\hline $20 \%$ ile & 1.70 & 1.36 & 1.52 & 1.53 & 1.41 & 1.32 & 1.15 & 0.52 & 2.19 & 5.28 & 8.21 & 5.68 \\
\hline $10 \%$ ile & 1.43 & 1.36 & 1.52 & 1.24 & 0.95 & 0.70 & 0.80 & 0.43 & 0.84 & 2.91 & 3.92 & 3.28 \\
\hline $1 \%$ ile & 1.20 & 1.19 & 0.89 & 0.88 & 0.40 & 0.22 & 0.00 & 0.04 & 0.32 & 0.49 & 0.84 & 1.59 \\
\hline
\end{tabular}


estuary. These were done with a network-based, monthly time-step Water Resource Yield Model (McKenzie and Van Rooyen, 1999) and covered as wide a range as possible of differences in volume and distribution of flows, and included different combinations of increasing the capacity of the existing dam (Clanwilliam) on the Olifants River by different amounts, options for dams on the Doring River, and increased abstraction in the headwaters of the Groot River (Table 5)

The anticipated future condition at each of the EF sites and the estuary, resulting from implementation of each scenario, was determined, and a socio-economic assessment, which considered the value of ecosystem goods, services and attributes and sectoral benefits of the off-stream use of water, was done.

The scenarios indicated opportunities for generating additional yield with relatively low environmental impact provided cognisance was taken of the dichotomy brought about by human utilisation of the area. The scenario that offered the most economically- and ecologically-balanced configuration (Scenario 5), comprised the following:

- Raise Clanwilliam Dam by $15 \mathrm{~m}$

- Allow limited additional water resource development in the headwaters of the Groot River

- Protect the Doring River (i.e., no in-channel dams or diversion weirs) and key tributaries on both the Olifants and Doring Rivers, to ensure the variability of flow in the main stems, and to provide refuges and source areas

- Maintain the present condition of the rivers at Sites 1, 3, 4, 5 and 6

- Maintain the present

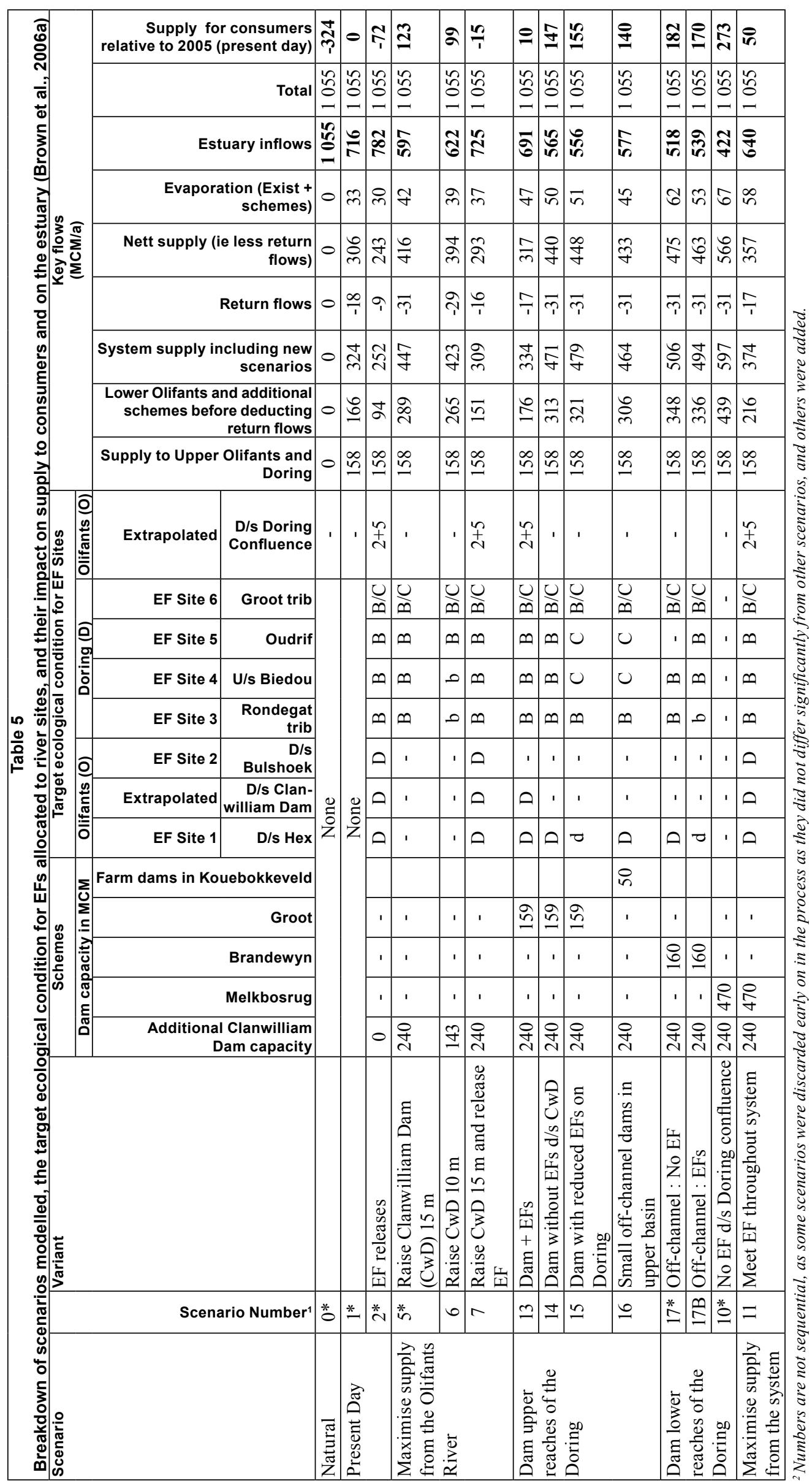


condition of Site 2, i.e., an E category. This effectively meant non-compliance to a Category $\mathrm{D}$ in the reach between Bulshoek Weir and the confluence with the Doring River (in return no in-channel dams or weirs in the Doring River).

- Maintain the present condition of the estuary, i.e. a C category.

Under the favoured section, the impacts on estuarine fisheries and nursery value were lowest, and the impacts on the livelihoods of small-scale fishers of Ebenhaeser, many of whom do not benefit from agriculture, were negligible. The scenario was further supported by the fact that dams in the Doring River had been repeatedly rejected as economically and ecologically unviable. They would also impact heavily on the estuary as the Doring River supplies much of the flow that supports the estuary (e.g. PGWC, 2003).

On the basis of the outcome of the basin-level EF assessment, the Director-General of the Department of Water Affairs and Forestry (now DWA) approved and officially signed-off a configuration of Preliminary Reserves for the basin that is in alignment with Scenario 5.

\section{The Clanwilliam Dam raising feasibility study}

The need for remedial work on Clanwilliam Dam provided a potential opportunity to raise the full supply level of the dam, and a feasibility study was undertaken to assess the technical, environmental, social, economic and financial viability of raising the dam wall by $5 \mathrm{~m}, 10 \mathrm{~m}$ and $15 \mathrm{~m}$.

Other bulk water options for increasing supply volumes for irrigation were also evaluated to ensure that DWA was aware of the full range of alternatives and implications and would thus be able to make an informed decision. As the social development needs in the region are extremely important, the study focused on opportunities for resource-poor farmers presented by the dam raising.

The options analysis re-evaluated many of the options considered in the basin-level EF assessment, but with a greater focus on technical, economic and financial feasibility of each. Fifteen surface water (and 11 groundwater) development options were evaluated in terms their capital to yield ratio; their environmental impacts (barrier/sediment, inundation and downstream effects); and their beneficiaries (cost, agricultural impact, benefits to users and resource-poor farmer opportunities).
Of the surface water options, the results mirrored those of the basin-level EF assessment in that the most favourable were the development of farm dams in the uppermost parts of the basin; the raising of Clanwilliam Dam, or a combination of the two (West and Luger, 2005). There was also broad support for the raising of Clanwilliam Dam from key stakeholders in the basin (West et al., 2007).

The current capacity of the Clanwilliam Dam is about $30 \%$ of the present day inflow to the impoundment and the proposed raising of the dam could increase the storage up to $100 \%$ of the present day inflow. If Clanwilliam Dam is raised then the dam will absorb more of the winter streamflows before it spills and as a result the spillage over the dam will be reduced and delayed.

\section{EF releases: temperature}

The current release structure at Clanwilliam Dam is a 'bottomrelease outlet', where water can only be released from the bottom of the dam. Thermal stratification in the impoundment means that water drawn off from a low level in the Dam during the spring and summer months is significantly colder $\left(12\right.$ to $\left.14^{\circ} \mathrm{C}\right)$ than the temperature in the downstream river $(18$ to $24^{\circ} \mathrm{C}$ ). This has serious implications for the Clanwilliam yellowfish (Labeobarbus capensis), which spawn downstream of the dam in the summer in response to small increases in discharge, but which will not spawn at temperatures below $18^{\circ} \mathrm{C}$ (Cambray et al., 1997; King et al., 1998). Hence, the temperature of water released from the bottom of the dam to cue spawning would render it ineffectual. The fish have managed to survive and spawn downstream of Clanwilliam Dam, because the size of the current impoundment is small relative to the MAR of the river, which means that the dam usually spills in late winter/early spring. However, increasing the height of the dam, and the attendant change in dam design, would mean that spillage from the dam would be considerably reduced, and spawning seriously affected.

Thus, a 'multilevel outlet works' with releases at various levels (and therefore different temperatures, salinity, etc.) was investigated using the 2-dimensional CE-QUAL-W2, laterally averaged, hydrodynamic and water quality simulation model (Kamish and Rossouw, 2006). The temperatures of the releases, with and without the multi-level outlet structure, are depicted in Fig. 3, which shows that it would be possible to meet the downstream temperature requirements in the summer using a multi-level offtake, provided the impoundment was full

Temperature of Releases from Clanwilliam Dam

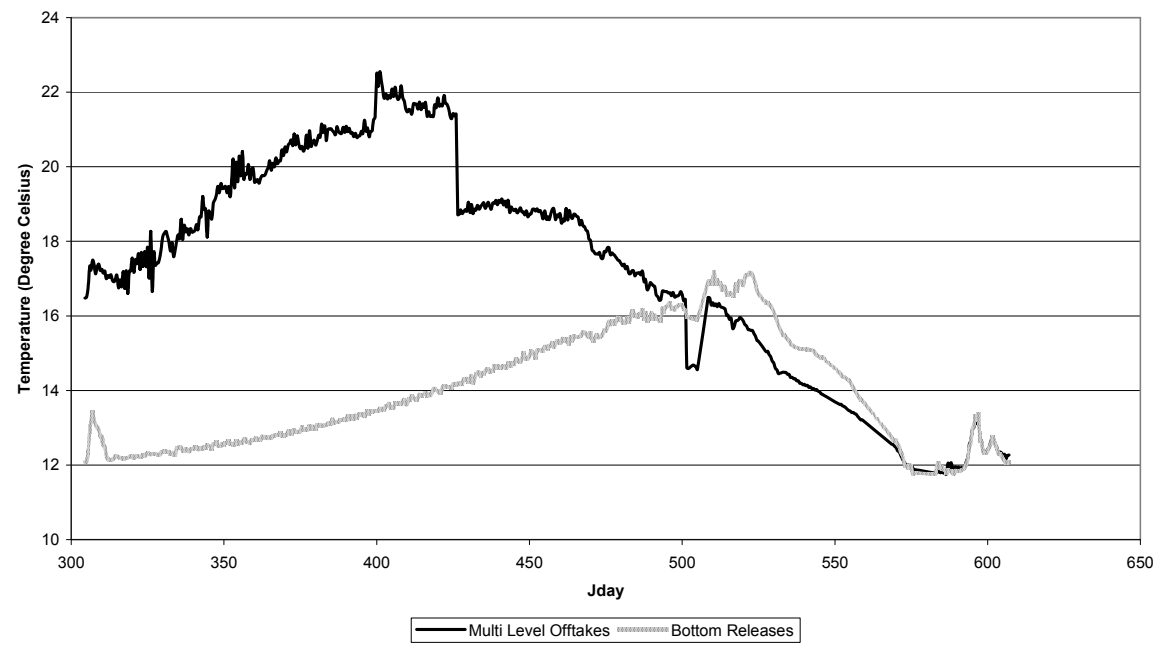

Figure 3

Temperature of dam releases made from the bottom releases and from the multi-level outlet structure, for a $15 \mathrm{~m}$ raising (Julian day $300=27$ October 1994) 
on 1 November, so that highest outlet could be used to make releases in early November.

On the basis of these results, a multi-level outlet structure was included in the proposed design, and costing, of the raised Clanwilliam Dam (Van der Berg and Killick, 2007).

\section{EF releases: hydrology and yield modelling}

The Water Resource Yield Model that was used in the basinlevel EF assessment of water resource development options was updated for use in the feasibility study (Sparks and Cullis, 2007). This entailed, inter alia, changes to some of the offstream demand and land-use data and some changes to the modelled hydrology (Table 6).

Scenarios were analysed to determine the historical yields of the system for the existing dam and for 3 different dam raisings of 5,10 and $15 \mathrm{~m}$. The scenarios also determined the influence on yield of making releases from Clanwilliam Dam to meet the EFs downstream of the Bulshoek Weir and at the estuary. Much of the focus of this was on meeting the requirements for maintaining a $\mathrm{C}$ category in the estuary (Table 4) and an E category at EF Site 2 (Table 7).

For the estuary, the Doring River, which contributes about $50 \%$ of the natural winter flow entering the estuary (Table 6), was used to supply the flood requirements and the bulk of the wet season low-flows. This was particularly valuable for Clanwilliam Dam, as it obviated the need to create a large outlet structure to release flood flows for the estuary (Sparks and Cullis, 2007). In the summer, a minimum inflow to the estuary of $1.5 \mathrm{~m}^{3} / \mathrm{s}$ was maintained. Historically the summer inflows to the estuary have been in the order of $2 \mathrm{~m}^{3} / \mathrm{s}$, decreasing to 0.8 to $1 \mathrm{~m}^{3} / \mathrm{s}$ in severe droughts. The shortfall in the low-flows at the head of the estuary during times of drought was supplied by releases from either Clanwilliam Dam or the Bulshoek Weir.

For EF Site 2, the wet season flows were supplied by spillage, and inflow from the surrounding catchment. In the summer the low-flows were supplied by releases from either Clanwilliam Dam or the Bulshoek Weir.

Off-channel yields were determined for 4 scenarios, namely:

- No EF releases

- Releases from Bulshoek/Clanwilliam to meet $1.5 \mathrm{~m}^{3} / \mathrm{s}$ summer low-flows into the estuary

- Releases from Bulshoek/Clanwilliam to meet the 'maintenance' EF summer low-flows at Site 2 (Table 7)

- Releases to meet the full EF requirements at Site 2 (Table 7; Sparks and Cullis, 2007).

For each, the historic firm yield (HFY, i.e., never failed) and the yield at a 1:10 year assurance of supply was calculated. In the past, leakage from the Bulshoek Weir (which has since been repaired), and

\begin{tabular}{|l|c|c|c|}
\hline \multicolumn{3}{|c|}{ Table 6 } \\
& $\begin{array}{c}\text { Natural and present day flows at key points } \\
\text { in the river system }\end{array}$ \\
\hline Keypoint & $\begin{array}{c}\text { Natural flow } \\
\text { (Mm } 3 / \text { a) }\end{array}$ & $\begin{array}{c}\text { Cumulative } \\
\text { present day } \\
\text { streamflow } \\
\text { (Mm } 3 \text { /a) }\end{array}$ & $\begin{array}{c}\text { \% of } \\
\text { natural }\end{array}$ \\
\hline EF Site 1 & 320.3 & 270.1 & $84 \%$ \\
\hline $\begin{array}{l}\text { Inflow to Clanwilliam } \\
\text { Dam }\end{array}$ & 410.3 & 355.7 & $87 \%$ \\
\hline Doring River & 515.4 & 405.8 & $79 \%$ \\
\hline Estuary & 1055.2 & 718.4 & $68 \%$ \\
\hline
\end{tabular}

high transmission losses between Clanwilliam and Bulshoek, meant that the supply failed more frequently than once in 10 years. If Clanwilliam Dam is raised, the increased storage will allow for a carry-over from year to year which will be used in drought years (Sparks and Cullis, 2007), thus reducing the number of failures.

The resultant yields for each of the 4 scenarios are shown in (Sparks and Cullis, 2007). If Clanwilliam Dam is not raised, and no EF releases are made, the 1:10 assurance yield is 174

\begin{tabular}{|c|c|c|c|c|c|c|c|}
\hline \multicolumn{8}{|c|}{$\begin{array}{c}\text { Table } 7 \\
\text { Details of the EF for maintaining an E category at EF Site } 2\end{array}$} \\
\hline \multicolumn{8}{|c|}{ Desktop Version 2, Generated on 11/08/2006 (version 2) } \\
\hline \multicolumn{8}{|c|}{ Total runoff: Quaternaries E10K } \\
\hline \multicolumn{8}{|c|}{ Annual Flows (Mill. cu. m or index values): } \\
\hline \multicolumn{8}{|c|}{$=519.676$} \\
\hline \multicolumn{3}{|c|}{ S.Dev. } & 38.570 & & & & \\
\hline \multicolumn{3}{|c|}{$\mathrm{CV}$} & 0.459 & & & & \\
\hline \multicolumn{3}{|c|}{ Q75 } & 2.246 & & & & \\
\hline \multicolumn{3}{|c|}{ Q75/MMF } & 0.052 & & & & \\
\hline \multicolumn{3}{|c|}{ BFI Index } & 0.314 & & & & \\
\hline \multicolumn{8}{|c|}{$\mathrm{CV}(\mathrm{JJA}+\mathrm{JFM})$ Index $=2.369$} \\
\hline \multicolumn{8}{|c|}{ Ecological Category $=\mathbf{E}$} \\
\hline \multicolumn{8}{|c|}{ Total IFR } \\
\hline \multicolumn{8}{|c|}{ Maint. Lowflow } \\
\hline \multicolumn{8}{|c|}{ Drought Lowflow } \\
\hline \multicolumn{8}{|c|}{ Maint. Highflow } \\
\hline \multicolumn{8}{|c|}{ Monthly distributions (Mill. cu. m.) } \\
\hline \multicolumn{8}{|c|}{ Distribution type: Western Cape (wet) } \\
\hline \multirow[t]{3}{*}{ Month } & \multicolumn{3}{|c|}{ Natural Flows } & \multicolumn{4}{|c|}{ Modified Flows (IFR) } \\
\hline & & & & & lows & $\begin{array}{c}\text { High } \\
\text { Flows }\end{array}$ & $\begin{array}{c}\text { Total } \\
\text { Flows }\end{array}$ \\
\hline & Mean & SD & CV & Maint. & Drought & Maint. & Maint. \\
\hline Oct & 39.933 & 15.648 & 0.392 & 2.458 & 2.458 & 0.000 & 2.458 \\
\hline Nov & 15.864 & 8.903 & 0.561 & 0.529 & 0.529 & 0.000 & 0.529 \\
\hline Dec & 4.857 & 4.538 & 0.934 & 0.546 & 0.546 & 0.000 & 0.546 \\
\hline Jan & 1.532 & 2.372 & 1.548 & 0.546 & 0.546 & 0.000 & 0.546 \\
\hline Feb & 1.335 & 2.386 & 1.787 & 0.493 & 0.493 & 0.000 & 0.493 \\
\hline Mar & 2.115 & 3.377 & 1.596 & 0.546 & 0.546 & 0.000 & 0.546 \\
\hline Apr & 9.449 & 15.047 & 1.592 & 0.529 & 0.529 & 0.000 & 0.529 \\
\hline May & 35.829 & 43.659 & 1.219 & 2.458 & 2.458 & 3.060 & 5.518 \\
\hline Jun & 94.724 & 89.304 & 0.943 & 2.379 & 2.379 & 3.060 & 5.439 \\
\hline Jul & 114.464 & 72.595 & 0.634 & 2.458 & 2.458 & 12.238 & 14.697 \\
\hline Aug & 118.849 & 71.102 & 0.598 & 2.458 & 2.458 & 12.238 & 14.697 \\
\hline Sep & 80.724 & 35.294 & 0.437 & 2.379 & 2.379 & 0.000 & 2.379 \\
\hline
\end{tabular}




\begin{tabular}{|c|c|c|c|c|c|c|}
\hline \multicolumn{7}{|c|}{$\begin{array}{c}\text { Table } 8 \\
\text { Yield analysis results }\end{array}$} \\
\hline \multirow{3}{*}{\multicolumn{2}{|c|}{ Scenario }} & \multirow{3}{*}{$\begin{array}{l}\text { Assurance } \\
\text { of supply }\end{array}$} & \multicolumn{4}{|c|}{ Total yield $\left(\times 10^{6} \mathrm{~m}^{3} / \mathrm{a}\right)$} \\
\hline & & & \multicolumn{4}{|c|}{ Dam raising } \\
\hline & & & $0 \mathrm{~m}$ & $5 \mathrm{~m}$ & $10 \mathrm{~m}$ & $15 \mathrm{~m}$ \\
\hline \multirow{2}{*}{$\mathrm{a}$} & \multirow{2}{*}{ No EF releases } & $1: 10$ & 175 & 219 & 248 & 275 \\
\hline & & HFY & 149 & 184 & 213 & 227 \\
\hline $\mathrm{b}$ & $1.5 \mathrm{~m}^{3} / \mathrm{s}$ at the estuary in drought years & HFY & 133 & 169 & 199 & 214 \\
\hline \multirow[b]{2}{*}{$\mathrm{c}$} & \multirow{2}{*}{ Low-flows at EF Site 2} & $1: 10$ & 161 & 196 & 225 & 254 \\
\hline & & HFY & 128 & 165 & 192 & 206 \\
\hline \multirow{2}{*}{ d } & \multirow{2}{*}{ Full EF at Site 2} & $1: 10$ & 154 & 183 & 207 & 239 \\
\hline & & HFY & 124 & 157 & 172 & 187 \\
\hline
\end{tabular}

$\mathrm{x} 10^{6} \mathrm{~m}^{3} / \mathrm{a}$, and the HFY is $149 \times 10^{6} \mathrm{~m}^{3} / \mathrm{a}$. This increases to $275 \times 10^{6} \mathrm{~m}^{3} / \mathrm{a}$, with a HFY of $227 \times 10^{6} \mathrm{~m}^{3} / \mathrm{a}$, if the dam is raised by $15 \mathrm{~m}$. If a flow of $1.5 \mathrm{~m}^{3} / \mathrm{s}$ into the estuary is maintained through releases from Clanwilliam Dam during drought years, and the dam is not raised, then HFY for the system is reduced by about $16 \times 10^{6} \mathrm{~m}^{3} / \mathrm{a}$ to $133 \times 10^{6} \mathrm{~m}^{3} / \mathrm{a}$. If the lowflow requirements at EF Site 2 are met and Clanwilliam Dam is raised by 5,10 or $15 \mathrm{~m}$ the Dam capacity increases to 184,264 and $362 \times 10^{6} \mathrm{~m}^{3} / \mathrm{a}$, respectively, resulting in HFYs of 165,192 and $206 \times 10^{6} \mathrm{~m}^{3} / \mathrm{a}$, respectively. Yields are lower if the full EF at Site 2 is met through releases from Clanwilliam Dam.

On the basis of these results, it was decided that if the dam is not raised and only dam safety work is undertaken then Scenario $b, 1.5 \mathrm{~m}^{3} / \mathrm{s}$ at the estuary in drought years, should be implemented. Making these releases from Clanwilliam Dam would affect the HFY, but would not negatively affect yield at a 1:10 assurance of supply and thus the economic costs of implementing the Reserve would be limited. The remainder of the flows will be provided by the Doring River, and spills from Clanwilliam Dam and Bulshoek. This would necessitate a moratorium on bulk water resource developments in the Doring River.

If the dam is raised, Scenario c, releases from Bulshoek/ Clanwilliam to meet the 'maintenance' EF summer low-flows at Site 2 and $1.5 \mathrm{~m}^{3} / \mathrm{s}$ at the estuary in drought years, was recommended for implementation. The remainder of the EF at Site 2 would be met by flow from the Jan Dissels River and spills at Clanwilliam Dam (Table 9).

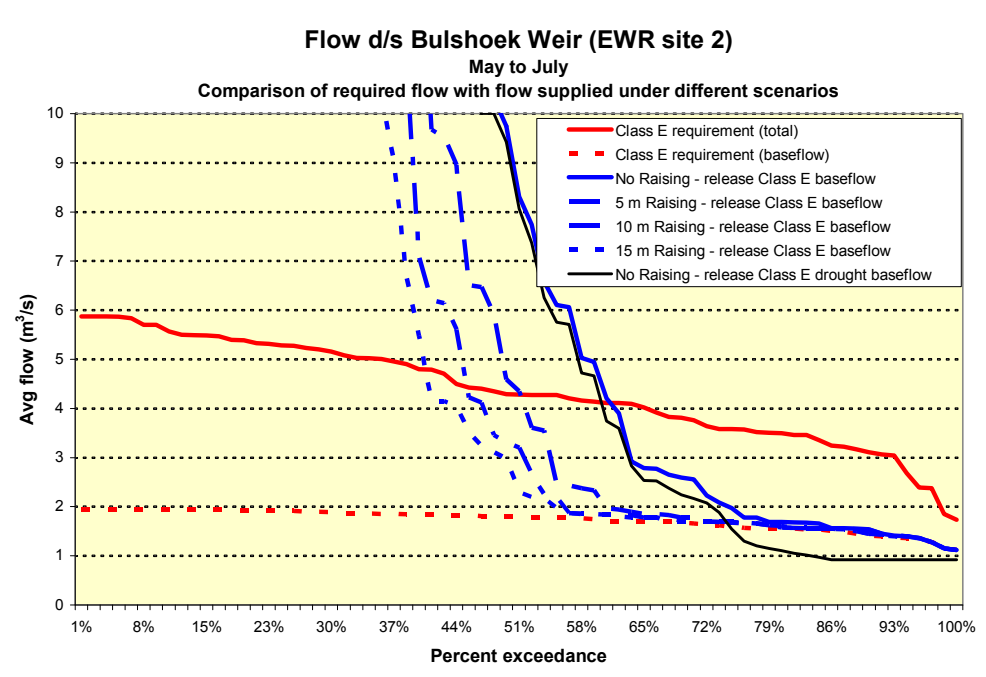

Figure 4

Flow d/s Bulshoek Weir for different scenarios (May to July)

\section{Operationalising the Reserve}

The assessments undertaken as part of the Clanwilliam Dam raising feasibility study were used to evaluate various approaches to implementing EFs in the basin and in so doing contribute to operationalising the ecological Reserve (DWAF, 1998).

Table 9 summaries the proposed approach, which was signed off by DWA, for operationalising the ecological Reserve for the Olifants River and its estuary, based on the notion of maximising the yield from the Olifants River.

\section{Discussion}

The agricultural sector relies heavily on the water resources of the Olifants-Doring Basin, and is responsible for $95 \%$ of water use in the area. It also contributes approximately $45 \%$ of the economic output of the basin (Shippey and Van der Berg, 2004) and is the major source of jobs. The areas that are most suitable for agriculture and most extensively cultivated often experience shortages in meeting water demands, and there is a need for an improved assurance of supply for irrigated agriculture as well as the need to allocate water to resource-poor farmers in these areas.

In this setting, despite the clear and urgent need to provide some protection to the aquatic ecosystems that form the resource base on which the basin depends, the introduction of onerous EFs could have significant negative implications for the agricultural sector and for the socio-economic wellbeing of the basin as a whole, which could have knock-on negative impacts on the natural environment. Thus, there is an excellent chance that unnecessarily onerous EFs would do more harm than good.

There are, however, some options in the Olifants/Doring Basin for generating additional yield with relatively low environmental impact, presenting a rare opportunity to achieve a true balance between development and protection of the aquatic environment (Brown et al., 2006a). Of the scenarios considered, Scenario 5 offered the most economically- and ecologically-balanced configuration, based on maximising yield from the Clanwilliam Dam (possibly augmented by some off-channel farm dams in the upper reaches of the Doring River). Scenario 5 comprised raising Clanwilliam Dam by up to $15 \mathrm{~m}$ and meeting the full requirements for the recommended ecological Reserve at 5 of the $8 \mathrm{EF}$ river sites, and at the estuary. The 3 sites where the full EFs would not 


\begin{tabular}{|c|c|c|c|}
\hline $\mathbf{I}$ & T) & $\begin{array}{c}\text { Table } 9 \\
\text { ed approach for operationalising the ecol }\end{array}$ & or the Olifants River and its estuary \\
\hline River & Reach & Issue & Proposed solution with a raised CwD \\
\hline Olifants & $\begin{array}{l}\text { Upstream } \\
\text { of CwD }\end{array}$ & Current EC: D & $\begin{array}{l}\text { Target EC: C, with improved management of non-flow } \\
\text { impacts to increase to C }\end{array}$ \\
\hline & & Present-day flows good, except for cessation & Meet EF, including summer low-flows \\
\hline & & $\begin{array}{l}\text { of flow in summer months when run-of-river } \\
\text { abstractions exceed available flows }\end{array}$ & $\begin{array}{l}\text { Compliance monitoring to ensure that irrigators do not } \\
\text { intercept these EFs }\end{array}$ \\
\hline & & & Encourage development of limited off-stream storage \\
\hline & \begin{tabular}{|l|} 
CwD \\
Dam to
\end{tabular} & Current EC: D & $\begin{array}{l}\text { Target EC: D, with improved spawning opportunities } \\
\text { for yellowfish }\end{array}$ \\
\hline & $\begin{array}{l}\text { Bulshoek } \\
\text { Weir }\end{array}$ & $\begin{array}{l}\text { CwD bottom outlets not able to meet the EF dis- } \\
\text { charge- and temperature-requirements for small } \\
\text { floods in October to January to trigger the spawn- } \\
\text { ing of Clanwilliam yellowfish }\end{array}$ & Include multi-level outlets in raised $\mathrm{CwD}$ \\
\hline & & $\begin{array}{l}\text { CwD releases approx. } 8 \mathrm{~m}^{3} / \mathrm{s} \text { during the summer } \\
\text { months, significantly more than natural summer } \\
\text { flow }\end{array}$ & $\begin{array}{l}\text { Stagger irrigation releases as a series of small flood } \\
\text { events, rather than constant release of } 8 \mathrm{~m}^{3} / \mathrm{s}\end{array}$ \\
\hline & $\begin{array}{l}\text { Bulshoek } \\
\text { Weir to }\end{array}$ & Current EC: E & $\begin{array}{l}\text { Target EC: E, with improved spawning opportunities } \\
\text { for yellowfish }\end{array}$ \\
\hline & 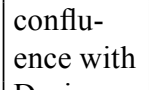 & $\begin{array}{l}\text { Until } c a .2004, \text { summer low-flows of about } 1.2 \\
\mathrm{~m}^{3} / \mathrm{s} \text { maintained by the leakage through the weir, }\end{array}$ & $\begin{array}{l}\text { Release EF low-flow requirements (Table 7) from CwD } \\
\text { as part of low-flow releases for estuary }\end{array}$ \\
\hline & Doring & although concessions were give to some down- & Withdraw concessions to use leakage \\
\hline & & $\begin{array}{l}\text { stream irrigators to use the leakage (estimated at } \\
0.5 \mathrm{~m}^{3} / \mathrm{s} \text { ). Repairs to weir reduced leakage to } 0.25 \\
\mathrm{~m}^{3} / \mathrm{s} \text {. }\end{array}$ & $\begin{array}{l}\text { Allow a portion of the staggered irrigation releases } \\
\text { from CwD to spill over the Bulshoek Weir to maintain } \\
\text { EF low-flow }\end{array}$ \\
\hline & & & $\begin{array}{l}\text { Early winter EF requirements will not be met but later } \\
\text { winter requirements will be exceeded. } \\
\text { Figure } 4 \text { shows that for May to July raising of CwD by } \\
15 \mathrm{~m} \text { results in reduced unregulated spills, and the total } \\
\text { EF being satisfied } 40 \% \text { as opposed to } 60 \% \text { of the time } \\
\text { if CwD is not raised. Low-flow requirements are met } \\
\text { throughout. }\end{array}$ \\
\hline & Estuary & Current EC: $\mathrm{C}$ with negative trajectory & Target EC: C \\
\hline & & $\begin{array}{l}\text { The present ecological state of the estuary was } \\
\text { may be worsening due to the low summer inflows }\end{array}$ & $\begin{array}{l}\text { Improved management of non-flow impacts to increase } \\
\text { to B }\end{array}$ \\
\hline & & $\begin{array}{l}\text { and non-flow related activities such as: } \\
\text { Over-exploitation of fish resources (gill net }\end{array}$ & $\begin{array}{l}\text { Releases from CwD and Bulshoek Weir to increase the } \\
\text { summer inflows to } 1.5 \mathrm{~m}^{3} / \mathrm{s}\end{array}$ \\
\hline & & $\begin{array}{l}\text { fisheries) } \\
\text { Nutrient inputs from agricultural activities }\end{array}$ & $\begin{array}{l}\text { Compliance monitoring to ensure that irrigators do not } \\
\text { intercept these EFs }\end{array}$ \\
\hline & & & $\begin{array}{l}\text { EF flood requirements provided by undeveloped Doring } \\
\text { River, plus spills from CwD }\end{array}$ \\
\hline Doring & All & Current EC: B & Target EC: B \\
\hline & & $\begin{array}{l}\text { Doring River provides } 50 \% \text { of the flows to the } \\
\text { estuary, including floods and winter low-flows. }\end{array}$ & $\begin{array}{l}\text { No major water-resource developments in the Doring } \\
\text { sub-basin }\end{array}$ \\
\hline & & $\begin{array}{l}\text { The Doring River and its main tributaries also } \\
\text { contain the bulk of the good quality fish habitat } \\
\text { remaining in the basin. }\end{array}$ & $\begin{array}{l}\text { Water-resource developments to be restricted to small } \\
\text { off-channel dams in the headwaters of the Groot River } \\
\text { (the main tributary of the Doring River) }\end{array}$ \\
\hline & & $\begin{array}{l}\text { Apart from the upper reaches of the Groot River, } \\
\text { the catchment of the Doring River is largely }\end{array}$ & $\begin{array}{l}\text { EFs at EF Sites } 4,5 \text { and } 6 \text { to be met in full - no } \\
\text { exceptions }\end{array}$ \\
\hline & & desert and unsuitable for large-scale agriculture & Mid-size and major floods to be unimpeded \\
\hline
\end{tabular}

be met are EF Site 2, downstream of Bulshoek Weir, and 2 extrapolated sites: EF Site 7, downstream of the confluence of the Olifants and Doring rivers and EF Site 8, between Clanwilliam Dam and Bulshoek Weir. Thus the general DWA policy guideline that all water resources should be managed in at least a Category D was not applied, as the benefit offered by the Doring River being left relatively untouched by water resource developments far outweighed those of 'forcing' the reach represented by EF Site 2 into a D category.
Under Scenario 5, the impacts on estuarine fisheries and nursery value are lowest, and thus so are the impacts on the livelihoods of small-scale fishers of Ebenhaeser, many of whom do not benefit from agriculture.

Provided that water resource developments are limited in the Doring River and it continues to provide the flood flows at the estuary, Scenario 5 also means that it is unnecessary to create large outlet capacity for a raised Clanwilliam Dam, as the outlet capacity required of Clanwilliam Dam is limited to that 
dictated by the EF requirements between Clanwilliam Dam and the confluence with the Doring River, i.e., approximately 20 $\mathrm{m}^{3} / \mathrm{s}$. This, of course, affects the costs of raising the dam.

Here we have shown that small adjustments in the EF requirements that form the ecological Reserve can greatly enhance the possibility, and reduce the costs, of successful implementation.

\section{Acknowledgements}

Our thanks to the many scientists, decision-makers, managers and local people who were involved in the work described in this paper; it was our privilege to work with them.

Information is used with permission from the RSA Department of Water Affairs, Chief Directorates Resource Directed Measures, National Water Resource Planning and Options Analysis. The key staff and authors of the Comprehensive Reserve Determination Study of the Olifants/ Doring Rivers, namely Southern Waters Ecological Research and Consulting cc, the CSIR Natural Resources and the Environment, and Ninham Shand (Pty) Ltd (now Aurecon), as well as all other contributing scientists, engineers and organisations, are specifically acknowledged.

This paper benefited greatly from comments by two anonymous reviewers, for which we thank them.

\section{References}

BESTER A, BRINK J, BEUKES J and RAMOKOPA W (2006). Feasibility Study for the Raising of Clanwilliam Dam, Feasibility Design of Raising Report. DWAF Report No. 20/2/E100-02/C/1/1. Department of Water Affairs and Forestry, South Africa.

BROWN CA and JOUBERT A (2003) Using multicriteria analysis to develop environmental flow scenarios for rivers targeted for water resource development. Water SA 29 (4) 365-374.

BROWN CA, PEMBERTON C and MAGOBA RN (2006a) Olifants Doring Catchment Ecological Water Requirements Study, Final Summary Report. Prepared by Southern Waters Ecological Research and Consulting cc for the Department of Water Affairs and Forestry. DWAF Report No. RDM/E000/MSR/01/CON/0606. Department of Water Affairs and Forestry, South Africa.

BROWN C, PEMBERTON C, BIRKHEAD A, BOK A, BOUCHER C, DOLLAR E, HARDING W, KAMISH W, KING J, PAXTON B and RATCLIFFE S (2006b) In support of water-resources planning - highlighting key management issues using DRIFT: a case study. Water SA 32 (2) 181-191.

CAMBRAY JA, KING JA and BRUWER C (1997). Reproduction behaviour and early development of the Clanwilliam yellowfish (Barbus capensis: Cyprinidae), linked to experimental dam releases in the Olifants River, South Africa. Regul. Rivers Res. Manage. 13 579-602.

DOLLAR ESJ, NICOLSON CR, BROWN CA, TURPIE JK, JOUBERT AR, TURTON AR, GROBLER, DF and MANYAKA SM (2010) The development of the South African Water Resource Classification System (WRCS): a tool towards the sustainable, equitable and efficient use of water resources in a developing country. Water Polic. 12 479-499.

DE WET SJ (2007) Feasibility Study for the Raising of Clanwilliam Dam, Draft Water Management Plan for the Olifants-Doorn Catchment Management Area Report. Prepared by SJ de Wet Consulting Services for the Department of Water Affairs and Forestry. DWAF Report No. P WMA 17/E10/00/1207. Department of Water Affairs and Forestry, South Africa.

KAMISH W and ROSSOUW JN (2006) Feasibility Study for the Raising of Clanwilliam Dam, Draft Water Quality Report. Prepared by Ninham Shand (Pty) Ltd for the Department of Water Affairs and Forestry, DWAF Report No. PWMA 17/E10/00/0506. Department of Water Affairs and Forestry, South Africa.
KEMPTHORNE A, VAN DER MERWE B and ALLEMEIER J (2007) Feasibility Study for the Raising of Clanwilliam Dam, Draft Socioeconomic Impact Assessment Report. Prepared by Urban-Econ for the Department of Water Affairs and Forestry. DWAF Report No. P WMA 17/E10/00/1707. Department of Water Affairs and Forestry, South Africa.

KING JM, BROWN CA and SABET H (2003). A scenario-based holistic approach to environmental flow assessments for regulated rivers. Rivers Res. Appl. 19 (5-6) 619-640.

KING JM, CAMBRAY JA and IMPSON ND (1998) Linked effects of dam-released floods and water temperatures on spawning of the Clanwilliam yellowfish Barbus capensis. Hydrobiol. 384 245-265.

KLEYNHANS CJ (1996) A qualitative procedure for the assessment of the habitat integrity status of the Luvuvhu River (Limpopo system, South Africa). J. Aq. Ecosys. Health 5 41-54.

LOW AB, MUSTART P and VAN DER MERWE H (2004) Greater Cederberg Biodiversity Corridor: Provision of Biodiversity Profiles for Management. Coastal and environmental consultants report prepared for The Project Management Unit, Greater Cederberg Biodiversity Corridor.

NWA (NATIONAL WATER ACT) (1998) Act No. 36 of 1998, Republic of South Africa. Government Gazette No. 19182. Government Printers. Pretoria.

PGWC (PROVINCIAL GOVERNMENT WESTERN CAPE, DEPARTMENT OF AGRICULTURE) (2003) Riverine Ecosystems Report. Prepared by Southern Waters Ecological Research and Consulting cc as part of Contract No. 259 2000/2001: Western Cape Olifants/Doring River Irrigation Study.

SKELTON PH, CAMBRAY JA, LOMBARD A and BENN GA (1995) Patterns of distribution and conservation status of freshwater fishes in southern Africa. S. Afr. J. Zool. 30 71-81.

SPARKS A and CULLIS J (2007) Feasibility Study for the Raising of Clanwilliam Dam, Draft System Analysis Report. Prepared by Ninham Shand for Department of Water Affairs and Forestry.. DWAF Report No. P WMA 17/E10/00/0607. Department of Water Affairs and Forestry, South Africa.

McKENZIE RS and VAN ROOYEN PG (1999) Water Resources Yield Model User Guide - Release 4.1.1. DWAF Report No. P0000/00/001/98. Department of Water Affairs and Forestry, Pretoria, South Africa. $156 \mathrm{pp}$.

SHIPPEY K and VAN DER BERG E (2004) Olifants Doorn Water Management Area: Internal Strategic Perspective Report. Prepared by Ninham Shand (Pty) Ltd. for Department of Water Affairs and Forestry. DWAF Report No. P WMA 17/000/00/0305. Department of Water Affairs and Forestry, Pretoria, South Africa.

TALJAARD S AND KEY SPECIALISTS (2006) Olifants Doring Catchment Ecological Water Requirements Study, RDM Report on Estuarine Component. Prepared by the CSIR for the Department of Water Affairs and Forestry, South Africa. CSIR Report No. CSIR/NRE/ECO/ER/2006/0038A/C. CSIR, South Africa.

TURPIE J, ADAMS JB, JOUBERT A, HARRISON TD, COLLOTY BM, MAREE RC, WHITFIELD AK, WOOLDRIDGE TH, LAMBERTH SJ, TALJAARD S and VAN NIEKERK L (2002) Assessment of the conservation priority status of South African estuaries for use in management and water allocation. Water SA 28 191-206.

VAN DER BERG E and KILLICK M (2007) Feasibility Study for the Raising of Clanwilliam Dam, Draft Financial Evaluation Report. Prepared by Ninham Shand (Pty) Ltd for the Department of Water Affairs and Forestry. DWAF Report No. PWMA 17/E10/00/1807. Department of Water Affairs and Forestry, South Africa.

WEST A and LUGER M (2005) Feasibility Study for the Raising of Clanwilliam Dam, Draft Screening of Options Report. Prepared by Ninham Shand (Pty.) Ltd. for the Department of Water Affairs and Forestry. DWAF Report No. P WMA 17/E10/00/0405. Department of Water Affairs and Forestry, South Africa.

WEST A, SHIPPEY K and ZIMMERMANN N (2007) Feasibility Study for the Raising of Clanwilliam Dam, Draft Environmental Impact Report. Prepared by Ninham Shand (Pty) Ltd for the Department of Water Affairs and Forestry. DWAF Report No. P WMA17/E/10/00/0907. Department of Water Affairs and Forestry, South Africa. 